This is an author produced version of a paper published in CROP PROTECTION. This paper has been peer-reviewed and is proofcorrected, but does not include the journal pagination

Citation for the published paper:

Wiik, L. (2009) Yield and disease control in winter wheat in southern Sweden during 1977-2005. Crop Protection. Volume: 28 Number: 1, pp 82-89.

http://dx.doi.org/10.1016/j.cropro.2008.09.002

Access to the published version may require journal subscription.

Published with permission from: Elsevier

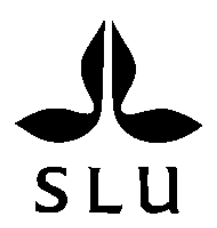

Epsilon Open Archive http://epsilon.slu.se 


\section{Yield and disease control in winter wheat in southern}

\section{Sweden during 1977-2005.}

3 Lars Wiik, SLU, Plant Protection Biology, PO Box 102, SE-230 53 Alnarp

$4 \quad$ Lars.Wiik@ltj.slu.se

\section{Abstract}

$7 \quad$ Fungicides are routinely used to prevent yield losses in winter wheat in southern Sweden.

8 Yield and 1000 grain weight (TGW) data from 432 trials in farmers' fields were evaluated to

9 review long-term yields (1977-2005) and control of eyespot and Leaf Blotch Diseases (LBDs, including Septoria tritici blotch, Stagonospora nodorum blotch and tan spot), powdery mildew, brown rust and yellow rust. Regression analyses revealed that control of LBDs explained 74\% of the yield increase achieved by fungicide treatment at GS 45-61, followed by powdery mildew (20\%), brown rust (5\%) and yellow rust (1\%). Yield of both untreated and fungicide-treated plots increased from approx. 6000 to $12000 \mathrm{~kg} \mathrm{ha}^{-1}$ over the period 1983-2005. Single eyespot treatment improved yield by $\sim 320 \mathrm{~kg} \mathrm{ha}^{-1} \mathrm{yr}^{-1}$ during the period 1977-2002, mainly due to occasional years with severe eyespot. Single leaf disease treatment at GS $45-61$ increased mean yield by $10.3 \%$ or $810 \mathrm{~kg} \mathrm{ha}^{-1} \mathrm{yr}^{-1}$ ( $9.9 \%$ or $660 \mathrm{~kg} \mathrm{ha}^{-1} \mathrm{yr}^{-1}$ for 1983-1994 and $10.7 \%$ or $970 \mathrm{~kg} \mathrm{ha}^{-1} \mathrm{yr}^{-1}$ for 1995-2005) due to increased TGW and grain numbers, especially in high yielding stands. Additional extra early treatment at GS 30-40 against LBDs increased yield by $\sim 250 \mathrm{~kg} \mathrm{ha}^{-1} \mathrm{yr}^{-1}$. Estimated variance in yield and TGW was higher between years than within years, while that in yield increase and plant diseases was lower between years than within. The results confirm potential and limits of fungicides and the need for supervised control strategies including factors affecting disease, yield and interactions. 
1 Keywords: 1000 grain weight, yield components, plant disease, Septoria tritici,

2 fungicides.

\section{1. Introduction}

4 Since 1980, the total area of arable land in southern Sweden has been decreasing, but the

5 mean acreage of winter wheat has increased from 50000 ha to 90000 ha, representing more

6 than 25\% of the total winter wheat acreage in Sweden (SCB, 1983-2006).

7 Leaf blotch diseases (LBDs) on winter wheat caused by Mycosphaerella graminicola

8 (anamorph Septoria tritici), Pyrenophora tritici-repentis (anamorph Drechslera tritici-

9 repentis) and Phaeosphaeria nodorum (anamorph Stagonospora nodorum), are the most

serious cereal pathogens in Sweden (Wiik et al., 1995; SJV, 2008). Other diseases such as

11 powdery mildew (Blumeria graminis), brown rust (Puccinia triticina) and yellow rust

12 (Puccinia striiformis) also contribute to yield losses due to the destruction of green leaf area,

13 in particular on the two top leaves (Shaw \& Royle, 1989a) and ears. Eyespot caused by the

14 sibling fungal species Oculimacula acuformis and O. yallundae (earlier described as one

15 fungus with the anamorph Pseudocercosporella herpotrichoides), is important and sometimes

16 requires fungicide treatment (SJV, 2008).

17 As in other countries, results from field trials have been used in Sweden to give

18 recommendations on fungicide products, timing and dosages (e.g. Cook \& Thomas, 1990). In

19 recent decades, a fungicide treatment against LBDs just before/during heading [growth stage

20 (GS) 47-55 according to Tottman, 1987] has been profitable in most years and is now routine

21 for many farmers in southern Sweden (SJV, 2008). When tan spot caused by D. tritici-

22 repentis is a problem, a split application at GS 37-39 and GS 55-59 is recommended.

23 However, in years when LBDs are inhibited due to dry conditions, the use of fungicides has

24 been questioned (Wiik, 1993). For many diseases such as the LBDs, eyespot, powdery 
1 mildew and rusts, the use of threshold values or warning forecasts aid decisions regarding

2 treatment. Winter wheat diseases, treatments and yield levels have been regularly studied in

3 field trials and reviewed (e.g. Andersson et al., 1986 and Wiik et al., 1995). However, there

4 are few scientific studies of the impact and dynamics of diseases on yield and yield loss over

5 longer periods of time.

6 This study evaluates the results from field trials 1977-2005 for eyespot and, 1983-2005 for

7 leaf diseases. The objectives were to examine the relationships between fungicide treatments

8 and yield and multiple diseases and yield, and to determine variations in yields and diseases

9 within and between years.

\section{Materials and methods}

11 Data were obtained from 432 trials in winter wheat fields on farms in southern Sweden $\left(55^{\circ} 23^{\prime}-56^{\circ} 25^{\prime} \mathrm{N}, 12^{\circ} 50^{\prime}-14^{\circ} 31^{\prime} \mathrm{E}\right)$ in the period $1977-2005$. The trials investigated different treatment strategies and fungicides applied at GS 30-61 in different cultivars and at different nitrogen levels and were carried out by staff at the Rural Economy and Agricultural Societies.

\subsection{Cultural practices in commercial fields and cultivars}

In general, sowing, fertilisation, weed and insect pest control were performed by farmers, the field trials included. The field trials were predominantly situated on good agricultural soils with a mean content of $17 \%$ clay and $3.3 \%$ organic matter and an adequate supply of phosphorus and potassium. Mean sowing date for winter wheat was 18 September (range 11 September - 3 October) and mean harvest date was 23 August (range 5 August - 25 September). The period from sowing to harvest was 340 days (range 314-375 days). Mean mineral nitrogen $(\mathrm{N})$ applied during the period was $155 \mathrm{~kg} \mathrm{~N} \mathrm{ha}^{-1}$ and mean total $\mathrm{N}$ including estimated available soil $\mathrm{N}$ from the preceding crop and from manure was $177 \mathrm{~kg} \mathrm{~N} \mathrm{ha}^{-1}$. The preceding crop was oilseed rape (54\%), cereals other than wheat (17\%), leguminous plants 
1 (9\%), wheat (7\%) and other crops (13\%). The most common cultivars in the field trials 1977-

21982 were Solid (49\%), Holme (20\%), Helge (17\%), Folke (7\%), Hildur (5\%) and Walde

3 (2\%) and in the field trials 1983-2005 Kosack (33\%), Folke (13\%), Ritmo (10\%) and Kris

4 (7\%). The cultivars Holme, Kraka, Konsul, Meridien, Bercy, Bill and Marshal represented 2-

$53 \%$ respectively, while another 17 cultivars represented less than $2 \%$ each. Folke

6 predominated 1983-1986, while Kosack was used in over 60\% of trials 1987-1994. Ritmo

7 predominated 1995-2000 and Kris 2001-2005. Field trials 1977-1994 used 2-4 cultivars per

8 year, while field trials 1995-2005 used 5-8 cultivars.

9

\subsection{Field trial design}

The trials were randomised in a block design with four replicates. The number of treatments per trial differed during the period but each usually included about 10 treatments and an untreated control. Plot size was usually 4 x 12 m and harvested area (excluding border rows) was $2 \mathrm{~m}$ x $10 \mathrm{~m}$, i.e. $20 \mathrm{~m}^{2}$ per plot.

\subsection{Fungicides and fungicide treatments}

Different types of fungicides and fungicide combinations containing active ingredients such as benzimidazoles, aromatics, morpholines, azoles, amides, strobilurins and pyrimidines were used in the field trials. Standard products at recommended dosages were generally used, e.g. $0.5 \mathrm{~L} \mathrm{ha}^{-1}$ Tilt 250 EC, a.i. propiconazole $250 \mathrm{~g} \mathrm{~L}^{-1}$; 0.8-1.0 L ha ${ }^{-1}$ Tilt Top 500 EC, a.i. propiconazole $125 \mathrm{~g} \mathrm{~L}^{-1}+$ fenpropimorph $375 \mathrm{~g} \mathrm{~L}^{-1}$; 0.5-1.0 L ha-1 Amistar, a.i. azoxystrobin $250 \mathrm{~g} \mathrm{~L}^{-1}$. Calibrated field crop sprayers with fan nozzles at a pressure of $300 \mathrm{KPa}$ pressure and $200 \mathrm{~L}_{\text {water }} \mathrm{ha}^{-1}$ were used as described in standard operating procedures of the Swedish GEP system.

Growth stages (GS) according to Tottman (1987) were used: Stem elongation [ear at $1 \mathrm{~cm}$ (pseudostem erect) (GS 30) to flag leaf ligule just visible (GS 39)]; Booting [flag leaf sheath 
1 extending (GS 40) to first awns visible (GS 49)]; Inflorescence (ear/panicle) emergence [first

2 spikelet of inflorescence just visible (GS 50) to emergence of inflorescence completed (GS

3 59)]; Anthesis (flowering) [beginning of anthesis (GS 60) to anthesis complete (GS 69)]; Milk

4 development [caryopsis (kernel) water ripe (GS 70) to late milk (GS 79)].

5 In addition to an untreated control, one or more of the following four treatments were

6 included in trials: 1) A single early treatment at GS 30-33 (mean GS 31 May 17) with

7 fungicides effective primarily against eyespot, 1977-2002; 2) a single treatment with

8 fungicides against LBDs, mildew, yellow rust and brown rust just before/during heading at

9 GS 45-61 (mean GS 53 June 14), 1983-2005; 3) a split treatment with fungicides against leaf

10 diseases including an early treatment at GS 31-40 followed by one at GS 45-61 and 4) a split

11 treatment with an early treatment at GS 30-33 primarily against eyespot, followed by a

12 treatment at GS 45-61with fungicides against leaf diseases. In early years, eyespot was

13 primarily treated with benzimidazoles and LBDs with azoles, but also amides and a conazole-

14 morpholine mixture. In later years, pyrimidines were generally used against eyespot and

15 strobilurins, conazoles and morpholines against leaf diseases, often in different combinations.

\section{$16 \quad 2.4$ Disease assessment}

17 The severity of leaf diseases on the top leaves was usually assessed before treatment and 3-5

18 weeks after last treatment (EPPO Standards, 2004) as percentage damage to flag leaf or top

19 leaf, leaf 2 or the leaf below the flag leaf, leaf 3 or the leaf below leaf 2 and leaf 4 or the leaf

20 below leaf 3. The necrotrophic LBDs caused by S. tritici, St. nodorum and D. tritici-repentis

21 were assessed as one disease due to mixed symptoms. If needed, disease severity at GS 55 on

22 leaf 3 and GS 75 on leaf 2 was estimated by additional assessments. The formula y=0.42* xii

23 [y=grain yield loss (\%) and xii=disease (\%) on leaf 2 (flag-1) in the range 0-45\%] (Thomas et

24 al., 1989; Cook et al., 1991) was used to estimate yield loss caused by LBDs. Fungicide 
1 efficacy was calculated as reduction in LBD-infected leaf area (\%) in treated plots compared

2 with untreated. An eyespot index was calculated from assessments on samples taken during

3 GS 65-77 as (\% weakly attacked tillers) $/ 4+(\%$ moderately attacked tillers) $/ 2+(\%$ severely

4 attacked tillers)/1, modified from Scott \& Hollins (1974).

\section{$5 \quad 2.5$ Yield}

6 The field trials were harvested with plot combines, mostly Hege and Sampo. Samples of $1 \mathrm{~kg}$

7 from each treatment were analysed for water content and 1000 grain weight (TGW). Yield

8 and TGW were reported at 15\% water content and grains $\mathrm{m}^{-2}$ were estimated from yield and

9 TGW. Degree of lodging (0-100, $0=$ upright stand and 100=totally lodging) was graded just

10 before harvest.

11 Actual yield responses due to a fungicide treatment at GS 45-61 for five disjunctive disease

12 severities were studied at high and low yield levels (high yield level $>9250 \mathrm{~kg} \mathrm{ha}^{-1}$ and low

13 yield level $<9250 \mathrm{~kg} \mathrm{ha}^{-1}$ based on yields for fungicide treatment at GS 45-61; and high yield

14 level $>8250 \mathrm{~kg} \mathrm{ha}^{-1}$ and low yield level $<8250 \mathrm{~kg} \mathrm{ha}^{-1}$ based on yields in untreated plots).

\subsection{Statistical methods}

17 Pearson-correlation, ANOVA, regression and variance component were analysed using SPSS

18 (ver. 13.0) (Hawkins, 2005). The Student-Newman-Keuls procedure with multiple range tests

19 was used to compare means. Variance component analyses (Restricted Maximum Likelihood

20 Estimation, REML) were used with year as random factor [GLM, var(year) and var(error)] to

21 differentiate effects within and between years for different variables. 


\section{3. Results}

\subsection{Yield}

Yields of both untreated and fungicide-treated winter wheat increased during the period 19832005 from $\sim 6000$ to $12000 \mathrm{~kg} \mathrm{ha}^{-1}$ (Figure 1). Mean yield was $8640 \mathrm{~kg} \mathrm{ha}^{-1}$ in treated field trials and $7830 \mathrm{~kg} \mathrm{ha}^{-1}$ in untreated. The annual increase in yield over the period was well described by linear regression and was $217 \mathrm{~kg} \mathrm{ha}^{-1} \mathrm{yr}^{-1}$ and $203 \mathrm{~kg} \mathrm{ha}^{-1} \mathrm{yr}^{-1}\left(\mathrm{R}^{2}=0.82, \mathrm{P}=\right.$ 0.001 and $\mathrm{R}^{2}=0.74, \mathrm{P}=0.001$ ) for treated and untreated field plots, respectively. A single treatment against eyespot improved yield by $320 \mathrm{~kg} \mathrm{ha}^{-1}$ on average, but this was due to a few years with severe eyespot attacks. A fungicide application just before/during heading resulted in an overall mean annual increase of $10.3 \%$ or $810 \mathrm{~kg} \mathrm{ha}^{-1}$ (9.9\% or $660 \mathrm{~kg} \mathrm{ha}^{-1}$ for 1983 1994, $10.7 \%$ or $970 \mathrm{~kg} \mathrm{ha}^{-1}$ for 1995-2005). An additional treatment at GS 31-40 against LBDs improved yield by a further $\sim 250 \mathrm{~kg} \mathrm{ha}^{-1}$. The yield increase due to fungicide treatment at GS 45-61 varied considerably between field trials within years and between years during the period (Tables 1 \& 2). The yield increases stratified into $250 \mathrm{~kg} \mathrm{ha}^{-1}$ increments fell into 11 classes within years (Table 2). The distribution of trials with increasing levels of yield increase due to a single treatment at GS 45-61 describes the variation in disease severity between years and also the variation between locations within this relatively limited geographical area. In nine years (eight prior to 1996) out of 23, 50\% of trials had yield increases of $<500 \mathrm{~kg} \mathrm{ha}^{-1}$. In 15 years, $50 \%$ of the trials had yield increase of $<1000 \mathrm{~kg} \mathrm{ha}^{-1}$. Mean annual yield increases of $1000 \mathrm{~kg} \mathrm{ha}^{-1}$ or more occurred in eight years $(1987,1990$, 1996, 1997, 1998, 1999, 2002 and 2003) and were very high in two of these (1987 and 2002). The TGW in untreated plots varied considerably between years (Table 1). The increase in TGW due to fungicide treatment just before/during heading was very small in some years but in a few years with high disease attacks it was as large as 7-9 g. There was a good correlation 
1 between yield and TGW within several years and a very high correlation between mean

2 annual yield increase and TGW $\left(\mathrm{R}^{2}=0.92\right)$. A $1 \mathrm{~g}$ increase in TGW due to a fungicide

3 treatment just before/during heading increased yield by $\sim 200 \mathrm{~kg} \mathrm{ha}^{-1}$. The number of grains $\mathrm{m}^{-}$

$4 \quad 2$ in untreated plots increased from $14-17$ to $20-24 \times 10^{3}$ during the period and the return on

5 the seed rate was thus 35- to 60-fold. Fungicide treatment just before/during heading

6 increased grain numbers, but the total yield increase was mainly due to an increase in TGW.

\section{$7 \quad 3.2$ Diseases}

8 Eyespot was quite common in some years (Table 1), but caused severe lodging only in

9 exceptional cases. Septoria tritici blotch was frequent in all years, while Stagonospora nodorum blotch and tan spot occurred mainly during the early and latter part of the study

11 period, respectively. Powdery mildew and rust were seen at low levels in many field trials, 12 with the exception of yellow rust in 1988 and 2002, brown rust in 1986, 1987 and 1990 and powdery mildew in the period 2000-2003 (Table 1). In some years, the rusts and powdery mildew were found on specific cultivars, e.g. yellow rust on Kraka 1988, brown rust on Folke and Kosack in the 1980s and powdery mildew on Florida, Bercy, Meridien, Marshal and Ritmo in later years.

In 1992, 1994 and 2004 LBD damage on leaf 2 did not reach 10\% severity at GS 75, while in 1997 it was >20\% and in 1987 and 2002 39\% or more (Figure 2). Fungicide treatment just before/during heading resulted in very high yield increases during 1987 and 2002, moderately high yield increases in 1997 and 2004 and minor yield increases in 1992 and 1994 (Table 1). Mean fungicide efficacy for one treatment against LBDs just before/during heading was 52\%, but in some years it was <40\% $(1983,1986,1989,1991,1996)$ and in others $>60 \%$ (1987, 1988, 1990, 1993, 1994, 1997, 1998) (Table 1). Fungicide efficacy often differed significantly between years, e.g. the very low efficacy in 1996 (18\%) and 1989 (23\%) was statistically different from all years except 1983, 1984, 1986, 1991, 1992 and 2004. 
1 Disease severity of LBDs on different leaf levels and growth stages was mostly significantly

2 correlated. There was also a correlation between diseases, e.g. yellow rust and LBDs (0.53,

$3 \mathrm{P}=0.017)$ and between eyespot and the efficacy of LBD control $(-0.49, \mathrm{P}=0.018)$.

\section{$4 \quad 3.3$ Yield and disease}

5 In two years (1983 and 1996), average eyespot index was $>35$ and mean yield response to

6 early treatment ( GS 31) with anti-eyespot fungicides was $1050 \mathrm{~kg} \mathrm{ha}^{-1}$ whereas it was only

$7 \quad 190 \mathrm{~kg} \mathrm{ha}^{-1}$ in years when eyespot index was <10 (1987, 1988, 1992 and 1994).

8 In regression analyses with the constant omitted and with yield increase due to fungicide

9 treatment as dependent variable and leaf diseases as predictors, LBDs explained $74 \%$ of the yield increase $(\mathrm{P}=0.001)$, followed by powdery mildew (20\%, $\mathrm{P}=0.021)$, brown rust $(5 \%$, ns) and yellow rust $(1 \%, \mathrm{~ns}), \mathrm{R}^{2}=0.82$. With the formula to predict disease (Cook et al., 1991), the mean yield loss due to LBDs was 6.6\% in untreated plots in this study (range $0.8-1.7 \%$ in years with very low attacks and 16-19\% in years with severe attacks) (Table 1).

The yield increase due to fungicide treatments was correlated to LBD disease severity at later stages, e.g. on leaf 2 at GS 75 (Pearson correlation coefficient 0.596, P=0.003), but not at earlier stages, e.g. on leaf 3 at growth stage GS 55 (0.240 ns) (Figure 3). Disease severity of >5\% during GS 55 on leaf 3 (e.g. 1987, 1996, 2002 and 2003) gave a yield increase due to fungicide treatment of $1000 \mathrm{~kg} \mathrm{ha}^{-1}$ or more. However, in other years (1990, 1997, 1998 and 1999) the yield increase was still $>1000 \mathrm{~kg} \mathrm{ha}^{-1}$ but the severity of attack on leaf 3 at GS 55 was rather low (Figure 3).

LBD severity on both leaf 3 at GS 55 and leaf 2 at GS 75 was significantly negatively correlated with yield level (Table 3). In contrast, powdery mildew was significantly positively correlated with yield level while brown rust showed no significant difference. Actual yield responses due to a fungicide treatment just before/during heading at five disjunctive disease 
1 severities and two yield levels based on fungicide-treated yields at GS 45-61 were greater at

2 the higher yield level than the lower (Table 4). In contrast, yield response was lower for the

3 higher of two yield levels based on untreated yields (Table 5).

\subsection{Variation within and between years}

Variance component analyses for different variables with year as random factor showed that total yield, yield increase, TGW, lodging and all diseases were affected by year (Table 6). The estimated variance of yield and TGW was larger between years than within years, whereas that of yield increase and plant diseases was smaller (Table 6).

\section{Discussion}

The doubling in actual grain yield 1983-2005 in both untreated and treated plots is probably due to a combination of factors. Grain yield is the outcome of the energy generated by photosynthesis and a multitude of interactions between genotype, various physiological processes, environment, agricultural practices and yield constraints. Yield gain in cultivars released during the latter half of the $20^{\text {th }}$ century is due to some genetic improvements, e.g. shorter cultivars with lodging resistance and high harvest index, more grains per unit area, earlier anthesis and longer grain filling period, higher $\mathrm{N}$ use efficiency and disease resistance, and improved agricultural practices (Slafer \& Andrade, 1993; Bockus et al., 2001; BrancourtHulmel et al., 2003). In France, 30-50\% of the increase in national yield 1956-1999 has been attributed to genetic improvements (Brancourt-Hulmel et al., 2003). In China, the eightfold increase in grain yield in cultivars released during 1945-1995 is mostly attributed to cropping practices and not genetic gain (Jiang et al., 2003).

Several high-yielding and early maturing modern continental cultivars of wheat were introduced in Sweden during the 1990s due to milder winters. For the period 1995-2005 of this study, when cultivars such as Ritmo and Kris predominated, mean yield in untreated plots 
1 was $9080 \mathrm{~kg} \mathrm{ha}^{-1}$ compared with $6680 \mathrm{~kg} \mathrm{ha}^{-1}$ for period 1983-1994, when low-yielding and

2 late maturing bread wheat cultivars such as Folke and Kosack were used. This yield

3 difference can be attributed to a $4.4 \%$ increase in TGW and a $29 \%$ increase in the mean

4 number of grains $\mathrm{m}^{-2}$. Mean yield per ha in the 1980s was similar to that reported in official

5 statistics for Sweden, but the mean annual increase in yield of $\sim 210 \mathrm{~kg} \mathrm{ha}^{-1} \mathrm{yr}^{-1}$ is much

6 higher than the $81 \mathrm{~kg} \mathrm{ha}^{-1} \mathrm{yr}^{-1}$ in Swedish statistics (SCB, 1983-2006), $110 \mathrm{~kg} \mathrm{ha}^{-1} \mathrm{yr}^{-1}$ in the

7 UK 1948-1997 (Austin, 1999) and $126 \mathrm{~kg} \mathrm{ha}^{-1} \mathrm{yr}^{-1}$ in France 1956-1999 (Brancourt-Hulmel et

8 al., 2003). Better soils, cultivars and agricultural practices in the field trials than in wheat

9 crops in general might explain the higher yield increase in this study.

The change from low- to high-yielding cultivars during the mid-1990s corresponded approximately with the change from azole to strobilurin fungicides. The latter probably explains the higher yield increase of $970 \mathrm{~kg} \mathrm{ha}^{-1}$ achieved by fungicide treatment during the latter period of this study compared with $660 \mathrm{~kg} \mathrm{ha}^{-1}$ in earlier years. A similar difference between fungicide types was reported by Bayles (1999) in the UK.

The photosynthetic activity of wheat upper foliage post-anthesis is the main source of assimilates distributed to the grains, but assimilates formed pre-anthesis can later be translocated to grains, e.g. as a buffer against stress if post-anthesis photosynthesis is disturbed (Wang et al., 1998). The use of fungicides to control plant disease, especially LBDs, keeps the upper foliage healthy and increases green leaf area duration thus promoting high grain yields (Bryson et al., 2000). For example, Gooding et al. (2000) showed that the mean grain weight increased by $1.15 \%$ per day when senescence of the flag leaf was delayed. Fungicides applied at flag leaf appearance (GS 39 or T2) have given the best yield gain in the UK (Cook \& Thomas, 1990; Hardwick et al., 2001). In the present study, yield (particularly 
1 yield increase due to a single late fungicide treatment at GS 45-61) was strongly linked to

2 increased TGW, confirming results by e.g. Gooding et al. (2000).

3

4 In this study, control of eyespot fungi with fungicides was very high in two out of 26 years

5 and in a few field trials where eyespot attack led to lodging. Previous studies in Sweden also

6 indicated that eyespot in wheat at GS 30-32 only repaid labour and fungicide costs in 15-20\%

7 of cases (Wiik et al., 1995). However, when the eyespot index exceeded 30 in the untreated

8 control at GS 75-77 and led to lodging, fungicide treatment at GS 30-32 was very profitable.

9 Earlier studies show that higher yield increases can be achieved when fungicide treatment suppresses lodging (Scott \& Hollins, 1978), but factors other than eyespot attack may also be 11 involved (Wiik, 1986).

12 Statistical analyses of the influence of single and multiple disease attacks on yield response showed that LBDs damaged leaf area most and gave the highest yield response to fungicide treatment at GS 45-61. Predictions of loss in grain yield proved fairly accurate for average LBD severity on leaf 2 at GS 75 over all years in this study. However, in some years the correlation between the actual yield increase due to fungicides and the estimated yield loss predicted by the formula was fairly low $\left(\mathrm{R}^{2}=0.47, \mathrm{P}=0.0003\right)$. This may be due to the interaction of other diseases, e.g. in 1983 when severe eyespot attacks masked the effect of the LBDs and in other years when control of the rusts contributed to the yield response. Moreover, the predictions originate from a critical point model, which might oversimplify the damage function (Shaw \& Royle, 1989a). Powdery mildew followed the LBDs as the second most important leaf disease overall in this study. Rusts were generally of minor importance most likely due to successful resistance breeding (McIntosh \& Brown, 1997), but can have a substantial effect on yield (e.g. Bockus et al., 2001). Brown rust and not mildew was the second most important disease after LBDs during the period 1983-1994 of this study. 
2 Stagonospora leaf and glume blotch (St. nodorum) caused severe attacks in Sweden during the 3 1970s, but since the 1980s S. tritici has become more important than St. nodorum in Sweden

4 and other countries, e.g. England and Wales (Hardwick et al., 2001; Shaw et al., 2008). In this

5 study Stagonospora nodorum blotch, Septoria tritici blotch and tan spot were assessed

6 together as LBDs although with new methods they can now be separated (Guo et al., 2007).

7 Powdery mildew attack has increased and brown rust has decreased in southern Sweden since

8 the 1990s in contrast to England and Wales, probably a result of national choice of cultivars

9 and host resistance to mildews and rusts. For example Ritmo is clearly more susceptible to mildew and Kris is more resistant to brown rust than Kosack (Larsson et al., 2005).

As diseases and pests in wheat most often coexist and interact, a multi-disease approach is essential (Kranz, 2005), although the focus must remain on the LBDs. The positive correlation between yellow rust and LBDs found in this study is not in agreement with glasshouse studies where rust development was repressed by the Septoria tritici blotch (Madariaga \& Scharen, 1986). Powdery mildew has been reported to predispose plants to Septoria tritici infection (Brokenshire, 1974), which might explain the significantly positive correlation between these diseases in this study.

Larsson (2005) demonstrated that the economic threshold for aphids (Sitobion avenae) in winter wheat decreased with higher yield. Similarly in the present study the yield increase achieved by a fungicide treatment at GS 45-61 was larger for the higher out of two yield levels based on yields treated with a fungicide at GS 45-61. Conversely at two yield levels based on untreated yields, the yield increase achieved by a fungicide treatment at GS 45-61 was smaller at the higher yield level, as was the LBD severity. Lovell et al. (1997) and 
1 Ewaldz (2000) suggested vertical upward movement of $S$. tritici inoculum to be less abundant

2 in a dense canopy, more impenetrable to rain splash than a thin canopy. Based on analysis of

3 field experiments on fungicide treatment at GS 39 during the period 1979-1987 Cook \&

4 Thomas (1990) suggested that higher yielding crops were more tolerant to foliar diseases and

5 gave the same absolute yield increase at different yield levels $\left(<6000 \mathrm{~kg} \mathrm{ha}^{-1}\right.$ to $>11000 \mathrm{~kg} \mathrm{ha}^{-}$

$6 \quad{ }^{1}$ ) but the percentage yield increase decreased with increasing potential yield level.

7

8 The recent change in grain prices will improve the profitability of a fungicide treatment for

9 the farmer as long as costs of production do not increase as much as the grain price. In

Sweden, treatment with a fungicide or a fungicide mixture against LBDs has to result in a

11 yield increase of between 225 and $680 \mathrm{~kg} \mathrm{ha}^{-1}$ to be a profitable investment (SJV, 2008),

12 depending on how the costs are estimated (grain price, choice of fungicide or fungicide

mixture, field pattern, sprayer equipment, labour, spray tracks or damage during application).

In this study, a profitable annual average yield increase was achieved in most years,

explaining why treatment just before or during heading has become routine for many farmers

in southern Sweden. Fungicide treatment against other diseases such as eyespot, rusts and mildew, normally not so frequent and devastating, is less profitable or not profitable.

However, some cultivars and specific conditions may promote attacks of these diseases, and during such circumstances treatment becomes profitable.

The progression towards higher yields and the variation within and between years is evident in these results, both in yield increase due to fungicidal input and severity of the diseases, and the results show the potential and limitations of fungicides in preventing yield losses. Another example of this variation is the difference in annual average yield increase (1980-1990) due to a fungicide treatment during GS 45-60 between southern Sweden (650 kg ha ${ }^{-1}$ due to a higher 
1 disease pressure) and central Sweden (240 kg ha $\left.{ }^{-1}\right)$ (Wiik, 1991). The variation within and

2 between years is caused by several factors, e.g. characteristics in the fungal populations

3 (Shaw \& Royle, 1989b; McDonald \& Linde, 2002), weather (Pietravalle et al., 2003), climate

4 (Coakley et al., 1999), management practices including nitrogen fertilisation level, choice of

5 crop, cultivar and fungicide and site factors (Cook \& Thomas, 1990; Simón et al., 2003;

6 Arraiano et al., 2006; Milne et al., 2007). This variation is reported from all over the world

7 and is logical as every field is unique, evidently in its location, and with its own history and

8 prerequisites of presence and prevalence of plant diseases, e.g. Septoria tritici and

9 Stagonospora nodorum (Leath et al., 1993). To improve future crop protection and to take the

right measures, e.g. supervised application of fungicides, more has to be learned about these

11 factors (Jeger, 2004; De Wolf \& Isard, 2007). A general conclusion from this study is the

12 great value of objective and impartial field trials well executed over consecutive years with comparable treatments and disease assessments, including necessary documentation of actions and further information. Results from such field trials can be used to optimise fungicide use from the perspective of farmers and of public authorities. In countries with similar conditions for wheat growing as in Sweden, treatment with an effective fungicide to protect the upper

17 leaves during grain filling will be of extreme importance unless cultivars with significantly improved resistance and management practices can be developed and applied. An extra treatment against LBDs at GS 31-40 was found to contribute to a yield increase, but in most 


\section{Acknowledgements}

2 The Swedish Farmers' Foundation for Agricultural Research (SLF) funded this research. My

3 sincere thanks for creative discussions and critical reviewing this paper goes to: Eva

4 Johansson, Erland Liljeroth, Arnulf Merker, and Jan-Eric Englund, Torbjörn Ewaldz, Lennart

5 Johnsson, Hans Larsson, Mary McAfee, Christer Nilsson, Lennart Pålsson, and Gunnar

6 Svensson.

\section{References}

8 Andersson, K., Larsson, H., Nilsson, I., Wiik, L., 1986. Försök med odlingssystem i höstvete i

9 Skåne 1978-1985. Engl. summary. SLU, Växtskyddsrapporter. Jordbruk 39, 211-233.

10

11 Arraiano, L.S., Brading, P.A., Dedryver, F., Brown, J.K.M., 2006. Resistance of wheat to septoria tritici blotch (Mycosphaerella graminicola) and associations with plant ideotype and 13 the 1BL-1RS translocation. Plant Pathol. 55, 54-61.

14

Austin R.B., 1999. Yield of winter wheat in the United Kingdom: Recent advances and prospects. Crop Sci. 39, 1604-1610.

Bayles, R., 1999. The interaction of strobilurin fungicides with cereal varieties. Plant Varieties and Seeds 12 (2), 129-140.

20

Bockus, W.W., Appel, J.A., Bowden, R.L., Fritz, A.K., Gill, B.S., Martin, T.J., Sears, R., wheat disease resistance in Kansas. Plant Dis. 85, 453-461. 
1 Brancourt-Hulmel, M., Doussinault, G., Lecomte, C., Bérard, P., Le Buanec, B., Trottet, M.,

2 2003. Genetic improvement of agronomic traits of winter wheat cultivars released in France

3 from 1946 to 1992. Crop Sci. 43, 37-45.

4

5 Brokenshire, T., 1974. Predisposition of wheat to Septoria infection following attack by

$6 \quad$ Erysiphe. Trans. Br. Mycol. Soc. 63, 2, 393-397.

7

Bryson, R.J., Leandro, L., Jones, D.R., 2000. The physiological effects of kresoxim-methyl on

wheat leaf greenness and the implications for crop yield. The BCPC Conference - Pest and

Diseases 7A-2, 739-746.

Coakley, S.M., Scherm, H., Chakraborty, S., 1999. Climate change and plant disease

management. Annu. Rev. Phytopathol. 37, 399-426.

14

Cook, R.J., Thomas, M.R., 1990. Influence of site factors in responses of winter wheat to

fungicide programmes in England and Wales, 1979-1987. Plant Pathol. 39, 548-557.

17

Cook, R.J., Polley, R.W., Thomas, M.R., 1991. Disease-induced losses in winter wheat in

England and Wales 1985-1989. Crop Prot. 10, 504-508.

De Wolf, E.D., Isard, S.A., 2007. Disease cycle approach to plant disease prediction. Annu.

Rev. Phytopathol. 45, 203-220.

23

EPPO Standards PP1, 2004. Efficacy evaluation of fungicides and bactericides. $2^{\text {nd }}$ Edition. 
1 Ewaldz, N.A.T., 2000. Radiometric readings as a tool for predicting optimal fungicide dose in

2 winter wheat. Z. Pflanzenkr. Pflanzenschutz 107, 594-604.

3

4 Gooding, M.J., Dimmock, J.P.R.E., France, J., Jones, S.A., 2000. Green leaf area decline of 5 wheat flag leaves: the influence of fungicides and relationships with mean grain weight and 6 grain yield. Ann. Appl. Biol. 136, 77-84.

7

8 Guo, J-R., Schnieder, F., Verreet, J-A., 2007. A real-time PCR assay for quantitative and

9 accurate assessment of fungicide effects on Mycosphaerella graminicola leaf blotch. J. Phytopathol. 155, 482-487.

Hardwick, N.V., Jones, D.R., Slough, J.E., 2001. Factors affecting diseases of winter wheat in England and Wales, 1989-1998. Plant Pathol. 50, 453-462.

Hawkins, D., 2005. Biomeasurement. Understanding, analysing, and communicating data in the biosciences. 284 p. Oxford University Press, UK.

17

Jeger, M.J., 2004. Analysis of disease progress as a basis for evaluating disease management practices. Annu. Rev. Phytopathol. 42, 61-82.

Jiang, G.M., Sun, J.Z., Liu, H.Q., Qu, C.M., Wang, K.J., Guo, R.J., Bai, K.Z., Gao, L.M., Kuang, T.Y., 2003. Changes in the rate of photosynthesis accompanying the yield increase in wheat cultivars released in the past 50 years. J. Plant Res. 116, 347-354. Tokyo. 
1 Kranz, J., 2005. Interactions in pest complexes and their effects on yield. Z. Pflanzenkr.

$2 \quad$ Pflanzenschutz 112, 366-385.

3

4 Larsson, H., 2005. A crop loss model and economic thresholds for the grain aphid, Sitobion

5 avenae (F.), in winter wheat in southern Sweden. Crop Prot. 24, 397-405.

6

7 Larsson, S., Hagman, J., Börjesdotter, D., 2005. Stråsäd, trindsäd, oljeväxter, potatis. Sortval 8 2005. SLU, Uppsala, Sweden.

9

Leath, S., Scharen, A.L., Lund, R.E., Dietz-Holmes, M.E., 1993. Factors associated with

11 global occurrences of Septoria nodorum blotch and Septoria tritci blotch of wheat. Plant Dis.

$12 \quad 77,1266-1270$.

13

14 Lovell, D.J., Parker, S.R., Hunter, T., Royle, D.J., Coker, R.R., 1997. Influence of crop

15 growth and structure on the risk of epidemics by Mycosphaerella graminicola (Septoria 16 tritici) in winter wheat. Plant Pathol. 46, 126-138.

17

18

Madariaga, R., Scharen, A.L., 1986. Interactions of Puccinia striiformis and Mycosphaerella graminicola on wheat. Plant. Dis. 70, 651-654.

20

McDonald, B.A., Linde, C., 2002. Pathogen population genetics, evolutionary potential, and durable resistance. Annu. Rev. Phytopathol. 40, 349-379.

23

24 McIntosh, R.A., Brown, G.N., 1997. Anticipatory breeding for resistance to rust diseases in 25 wheat. Annu. Rev. Phytopathol. 35, 311-326. 
2 Milne, A., Paveley, N., Audsley, E., Parsons, D., 2007. A model of the effect of fungicides on

3 disease-induced yield loss, for use in wheat disease management decision support systems.

$4 \quad$ Ann. Appl. Biol. 151, 113-125.

5

6 Pietravalle, S., Shaw, M.W., Parker, S.R., van den Bosch, F., 2003. Modeling of relationships

7 between weather and Septoria tritici epidemics on winter wheat: A critical approach.

8 Phytopathol. 93, 1329-1339.

9

SCB, 1983-2006. Yearbooks of agricultural statistics 1983-2006, official statistics of Sweden.

Scott, P.R., Hollins, T.W., 1974. Effects of eyespot on the yield of winter wheat. Ann. Appl.

Biol. 78, 269-279.

14

Scott, P.R., Hollins, T.W., 1978. Prediction of yield loss due to eyespot in winter wheat. Plant

Pathol. 27, 125-131.

17

18 Shaw, M.W., Royle, D.J., 1989a. Estimation and validation of a function describing the rate at which Mycosphaerella graminicola causes yield loss in winter wheat. Ann. Appl. Biol. 115, 425-442.

21

Shaw, M.W., Royle, D.J., 1989b. Airborne inoculum as a major source of Septoria tritici

(Mycosphaerella graminicola) infections in winter wheat crops in the UK. Plant Pathol. 38, 35-43. 
1 Shaw, M.W., Bearchell, S.J., Fitt, B.D.L., Fraaije, B.A., 2008. Long-term relationships

2 between environment and abundance in wheat of Phaeosphaeria nodorum and

3 Mycosphaerella graminicola. New Phytologist 177, 229-238.

4

5 Simón, M.R., Cordo, C.A., Perelló, A.E., Struik, P.C., 2003. Influence of nitrogen supply on 6 the susceptibility of wheat to Septoria tritici. J. Phytopathol. 151, 283-289.

7

SJV, 2008. Swedish Board of Agriculture, www.sjv.se/vsc, June 2008.

9

Slafer, G.A., Andrade, F.H., 1993. Physiological attributes related to the generation of grain yield in bread wheat cultivars released at different eras. Field Crops Res. 31, 351-367.

12

Thomas, M.R., Cook, R.J., King, J.E., 1989. Factors affecting development of Septoria tritici in winter wheat and its effect on yield. Plant Pathol. 38, 246-257.

15

Tottman, D.R., 1987. The decimal code for the growth stages of cereals, with illustrations. Ann. Appl. Biol. 110, 441-454.

18

Wang, Z., Yin, Y., He, M., Cao, H., 1998. Source-sink manipulation effects on postanthesis photosynthesis and grain setting on spike in winter wheat. Photosynthetica 35, 3, 453-459.

Wiik, L., 1986. Stråbassjukdomar i höstvete - en analys av olika variabler i 30 odlingssystemförsök i Skåne 1983-1985. Nordisk plantevernkonferanse 1986. Aktuelt fra 
1 Wiik, L., 1991. Ekonomisk betydelse av svampsjukdomar i stråsäd vid förändrade priser.

2 Engl. summary. 32:a svenska växtskyddskonferensen. Skadedjur och växtsjukdomar, 1713186.

4

5 Wiik, L., 1993. Väderleken och Septoria spp.: Sambandet mellan några klimatparametrar och 6 skördeförlusten orsakad av Septoria spp. Engl. summary. 34:e svenska

7 växtskyddskonferensen. Skadedjur och växtsjukdomar, 85-90. SLU, Uppsala, Sweden.

8

9 Wiik, L., Olofsson, B., Johnsson, L., Olvång, H., 1995. Sprutning mot skadesvampar i stråsäd 10 med fungicider 1976-1992. Engl. summary. SLU, Rapport 3, pp. 115. Alnarp, Sweden. 
Table 1. Mean annual incidence of eyespot (index) and percentage attack by LBDs (Septoria tritici, Stagonospora nodorum and Drechslera tritici-repentis), powdery mildew, brown rust, yellow rust, 1000 grain weight (TGW, g), no. of grains, actual and estimated yield increase $\left(\mathrm{kg} \mathrm{ha}^{-1}\right)$ in southern Sweden, 1983-2005

\begin{tabular}{|c|c|c|c|c|c|c|c|c|c|}
\hline Year & Eyespot & $\begin{array}{c}\text { LBDs on } \\
\text { leaf } 2 \text { DC } 75 \\
\left(\text { efficacy }^{3)}\right) \\
0\end{array}$ & $\begin{array}{c}\text { Mildew } \\
\text { max attack }\end{array}$ & $\begin{array}{l}\text { Brown rust } \\
\text { max attack }\end{array}$ & $\begin{array}{l}\text { Yellow rust } \\
\text { max attack }\end{array}$ & $\begin{array}{l}\text { TGW increase } \\
\text { (untreated TGW) }\end{array}$ & $\begin{array}{l}\text { Rel. increase } \\
\text { in no. of grains } \\
\text { (untreated grains } \mathrm{m}^{-2} \text { ) }\end{array}$ & $\begin{array}{c}\text { Actual yield } \\
\text { increase }^{1)} \\
\text { (untreated yield) }\end{array}$ & $\begin{array}{c}\text { Yield loss }^{2)} \\
\text { Cook et al. } 1991\end{array}$ \\
\hline & index & $\%$ & $\%$ & $\%$ & $\%$ & $\mathrm{~g}$ & no. & $\mathrm{kg} \mathrm{ha}^{-1}$ & $\%$ \\
\hline 1983 & 37 & $41(37)$ & 0,3 & 4,2 & 0,1 & $2.8(33.2)$ & $103(16602)$ & $630 \quad(5510)$ & 17.2 \\
\hline 1984 & 22 & $15(40)$ & 2,8 & 1,1 & 0,0 & $2.7(40.0)$ & 104 (16936) & $760 \quad(6770)$ & 6.3 \\
\hline 1985 & 13 & $9(51)$ & 0,2 & 0,7 & 0,0 & 0.7 (46.5) & 105 (13913) & $420 \quad(6480)$ & 3.8 \\
\hline 1986 & 20 & $15(33)$ & 0,6 & 7,3 & 0,0 & $0.9(47.8)$ & 104 (15076) & $430 \quad(7200)$ & 6.3 \\
\hline 1987 & 6 & $47(82)$ & 1,1 & 6,4 & 0,0 & $9.0(29.2)$ & $110(14336)$ & $1850(4180)$ & 18.9 \\
\hline 1988 & 9 & $24(63)$ & 1,2 & 2,4 & 4,0 & $3.1(42.2)$ & $104(17348)$ & $840 \quad(7310)$ & 10.1 \\
\hline 1989 & 29 & $11(23)$ & 0,3 & 1,2 & 0,2 & $0.8(42.2)$ & $100(15772)$ & $140 \quad(6650)$ & 4.6 \\
\hline 1990 & 32 & $14(71)$ & 0,3 & 10,1 & 1,0 & $5.9(41.4)$ & 102 (18223) & $1230 \quad(7540)$ & 5.9 \\
\hline 1991 & 30 & $24(34)$ & 0,3 & 0,3 & 0,0 & $4.3(37.8)$ & $101(18066)$ & $900 \quad(6830)$ & 10.1 \\
\hline 1992 & 4 & $2(41)$ & 0,0 & 0,0 & 0,2 & $0.1(41.8)$ & $102(16022)$ & $130 \quad(6700)$ & 0.8 \\
\hline 1993 & 14 & $2(64)$ & 2,1 & 2,6 & 0,0 & $1.6(48.3)$ & 101 (15778) & $320(7660)$ & 0.8 \\
\hline 1994 & 7 & $4(63)$ & 0,1 & 2,2 & 0,0 & $1.1(39.8)$ & $101(18317)$ & $260(7300)$ & 1.7 \\
\hline 1995 & 28 & $13(58)$ & 1,2 & 0,2 & 0,0 & $0.7(40.4)$ & 104 (19910) & $480 \quad(8050)$ & 5.5 \\
\hline 1996 & 38 & $11(18)$ & 1,0 & 0,0 & 0,0 & $0.4(37.0)$ & $111(19874)$ & $1000 \quad(7950)$ & 4.6 \\
\hline 1997 & 19 & $23(69)$ & 0,2 & 0,1 & 0,0 & $4.3(39.3)$ & $103(21308)$ & $1180 \quad(8370)$ & 9.7 \\
\hline 1998 & 22 & $8(61)$ & 1,0 & 0,0 & 0,0 & $5.6(41.2)$ & $102(20541)$ & $1360 \quad(8470)$ & 3.4 \\
\hline 1999 & 24 & $17(55)$ & 1,4 & 0,3 & 0,9 & $4.2(40.7)$ & $103(21361)$ & $1210(8680)$ & 7.1 \\
\hline 2000 & 24 & $7(56)$ & 13,0 & 0,0 & 0,0 & $3.2(51.8)$ & 101 (18894) & $770 \quad(9780)$ & 2.9 \\
\hline 2001 & 32 & $8(58)$ & 2,6 & 0,4 & 0,1 & $2.2(47.7)$ & $102(20430)$ & $640 \quad(9740)$ & 3.4 \\
\hline 2002 & 21 & $39(57)$ & 5,5 & 1,1 & 2,3 & $6.8(40.3)$ & $104(20780)$ & $1790 \quad(8370)$ & 16.4 \\
\hline 2003 & 21 & $7(51)$ & 5,6 & 0,3 & 0,1 & $3.3(39.8)$ & $104(22453)$ & $1100(8940)$ & 2.9 \\
\hline 2004 & 22 & $7(43)$ & 1,7 & 0,1 & 0,0 & $3.0(43.1)$ & $102(22436)$ & 910 & 2.9 \\
\hline 2005 & 22 & $15(56)$ & 0,1 & 0,1 & 0,0 & $0.6(48.9)$ & $101(24236)$ & $270(11860)$ & 6.3 \\
\hline Mean & 22 & $16(52)$ & 1,9 & 1,8 & 0,4 & $2.9(41.8)$ & $103(18635)$ & $810 \quad(7830)$ & 6.6 \\
\hline
\end{tabular}

1) The increase was achieved by a fungicide treatment just before/during heading.

2) Yield loss according to the formula by Cook et al. 1991, $\mathrm{y}=0.42 *$ xii [y=percentage loss in grain yield and xii=percentage disease leaf 2 (flag-1), in the range 0-45\%].

${ }^{3)}$ Fungicide efficacy, \%. 
Table 2. Frequency of yield increases from a fungicide treatment during growth stages DC 45-61, classes (I-XI) in $250 \mathrm{~kg}^{-1} \mathrm{steps}$ in field trials in southern Sweden during 1983-2005. Shaded area represents classes with at least 50\% of the trials of that year

\begin{tabular}{|c|c|c|c|c|c|c|c|c|c|c|c|c|}
\hline \multirow[t]{4}{*}{ Year } & \multirow[t]{4}{*}{ No. ${ }^{1)}$} & \multicolumn{11}{|c|}{$\begin{array}{l}\text { Yield increases from a fungicide treatment during growth stages DC } 45-61 \text { during } 23 \text { years (1983-2005) and several field trials } \\
\text { each year divided into } 11 \text { classes (I-XI) in accumulated steps of } 250 \mathrm{~kg} \mathrm{ha}^{-1} \text { in yield increase. }\end{array}$} \\
\hline & & I & II & III & IV & $\mathrm{V}$ & VI & VII & VIII & IX & X & XI \\
\hline & & $<249$ & $250-499$ & $500-749$ & $750-999$ & $1000-1249$ & $1250-1499$ & $1500-1749$ & $1750-1999$ & $2000-2249$ & $2250-2499$ & $>2500$ \\
\hline & & $\mathrm{kg} \mathrm{ha}^{-1}$ & $\mathrm{~kg} \mathrm{ha}^{-1}$ & $\mathrm{~kg} \mathrm{ha}^{-1}$ & $\mathrm{~kg} \mathrm{ha}^{-1}$ & $\mathrm{~kg} \mathrm{ha}^{-1}$ & $\mathrm{~kg} \mathrm{ha}^{-1}$ & $\mathrm{~kg} \mathrm{ha}^{-1}$ & $\mathrm{~kg} \mathrm{ha}^{-1}$ & $\mathrm{~kg} \mathrm{ha}^{-1}$ & $\mathrm{~kg} \mathrm{ha}^{-1}$ & $\mathrm{~kg} \mathrm{ha}^{-1}$ \\
\hline 1983 & 13 & 2 & 5 & 1 & 3 & 1 & 1 & 0 & 0 & 0 & 0 & 0 \\
\hline 1984 & 18 & 0 & 6 & 0 & 8 & 3 & 1 & 0 & 0 & 0 & 0 & 0 \\
\hline 1985 & 13 & 2 & 7 & 3 & 1 & 0 & 0 & 0 & 0 & 0 & 0 & 0 \\
\hline 1986 & 7 & 3 & 2 & 0 & 1 & 0 & 0 & 1 & 0 & 0 & 0 & 0 \\
\hline 1987 & 7 & 0 & 0 & 0 & 1 & 0 & 1 & 1 & 0 & 2 & 1 & 1 \\
\hline 1988 & 5 & 0 & 0 & 1 & 3 & 1 & 0 & 0 & 0 & 0 & 0 & 0 \\
\hline 1989 & 14 & 8 & 4 & 1 & 0 & 1 & 0 & 0 & 0 & 0 & 0 & 0 \\
\hline 1990 & 11 & 1 & 0 & 0 & 3 & 2 & 2 & 1 & 1 & 0 & 0 & 1 \\
\hline 1991 & 12 & 0 & 2 & 2 & 3 & 3 & 2 & 0 & 0 & 0 & 0 & 0 \\
\hline 1992 & 6 & 3 & 3 & 0 & 0 & 0 & 0 & 0 & 0 & 0 & 0 & 0 \\
\hline 1993 & 3 & 1 & 1 & 1 & 0 & 0 & 0 & 0 & 0 & 0 & 0 & 0 \\
\hline 1994 & 12 & 7 & 4 & 1 & 0 & 0 & 0 & 0 & 0 & 0 & 0 & 0 \\
\hline 1995 & 47 & 13 & 15 & 10 & 6 & 1 & 0 & 2 & 0 & 0 & 0 & 0 \\
\hline 1996 & 65 & 12 & 5 & 5 & 8 & 14 & 6 & 7 & 2 & 3 & 1 & 2 \\
\hline 1997 & 63 & 2 & 3 & 9 & 12 & 11 & 8 & 9 & 5 & 3 & 1 & 0 \\
\hline 1998 & 36 & 0 & 1 & 3 & 8 & 6 & 4 & 4 & 4 & 3 & 3 & 0 \\
\hline 1999 & 34 & 1 & 2 & 7 & 5 & 2 & 8 & 3 & 0 & 3 & 2 & 1 \\
\hline 2000 & 37 & 4 & 6 & 6 & 9 & 6 & 4 & 1 & 1 & 0 & 0 & 0 \\
\hline 2001 & 93 & 24 & 14 & 14 & 15 & 10 & 5 & 8 & 3 & 0 & 0 & 0 \\
\hline 2002 & 107 & 2 & 5 & 2 & 6 & 10 & 14 & 8 & 15 & 17 & 8 & 20 \\
\hline 2003 & 94 & 0 & 7 & 16 & 16 & 21 & 17 & 9 & 8 & 0 & 0 & 0 \\
\hline 2004 & 36 & 6 & 5 & 4 & 4 & 8 & 2 & 2 & 5 & 0 & 0 & 0 \\
\hline 2005 & 31 & 16 & 7 & 5 & 1 & 1 & 1 & 0 & 0 & 0 & 0 & 0 \\
\hline All years & 764 & 107 & 104 & 91 & 113 & 101 & 76 & 56 & 44 & 31 & 16 & 25 \\
\hline
\end{tabular}

${ }^{1)}$ No. = Number of field trials or different varieties and nitrogen levels within a field trial, treated with a fungicide just before or during heading. 
Table 3. Percentage LBDs \% (including S. tritici, S. nodorum, D. tritici-repentis), powdery mildew and brown rust, 1000 grain weight $(\mathrm{TGW}, \mathrm{g})$ and yield increase $\left(\mathrm{kg} \mathrm{ha}^{-1}\right)$ discriminated into five untreated yield levels $^{1)}$ 1983-2005. SNK-test ${ }^{2)}$ in each column marked by letters, $\mathrm{P}<0.05$

\begin{tabular}{ccccccc}
\hline $\begin{array}{c}\text { Yield in } \\
\text { untreated } \\
\mathrm{kg} \mathrm{ha}^{-1}\end{array}$ & $\begin{array}{c}\text { LBD on } \\
\text { leaf DC 55 } \\
\%\end{array}$ & $\begin{array}{c}\text { leaf 2 DC 75 } \\
\%\end{array}$ & $\begin{array}{c}\text { Powdery } \\
\text { mildew } \\
\%\end{array}$ & $\begin{array}{c}\text { Brown } \\
\text { rust } \\
\%\end{array}$ & $\begin{array}{c}\text { TGW } \\
\mathrm{g}\end{array}$ & $\begin{array}{c}\text { Yield } \\
\text { Increase }^{3)} \\
\mathrm{kg} \mathrm{ha}^{-1}\end{array}$ \\
\hline $3330-6990$ & $6.4 \mathrm{a}$ & $22.0 \mathrm{a}$ & $2.0 \mathrm{bc}$ & $1.3 \mathrm{a}$ & $37.2 \mathrm{~d}$ & $1010 \mathrm{a}$ \\
$7000-7990$ & $4.6 \mathrm{ab}$ & $17.8 \mathrm{ab}$ & $1.7 \mathrm{c}$ & $0.8 \mathrm{a}$ & $40.7 \mathrm{c}$ & $1010 \mathrm{a}$ \\
$8003-8970$ & $3.4 \mathrm{bc}$ & $14.8 \mathrm{bc}$ & $3.0 \mathrm{abc}$ & $1.3 \mathrm{a}$ & $40.9 \mathrm{c}$ & $1070 \mathrm{a}$ \\
$9010-9970$ & $2.3 \mathrm{c}$ & $13.4 \mathrm{bc}$ & $3.6 \mathrm{ab}$ & $0.6 \mathrm{a}$ & $43.0 \mathrm{~b}$ & $1060 \mathrm{a}$ \\
$10020-13520$ & $1.6 \mathrm{c}$ & $10.2 \mathrm{c}$ & $4.1 \mathrm{a}$ & $0.3 \mathrm{a}$ & $46.9 \mathrm{a}$ & $800 \mathrm{~b}$ \\
\hline $\mathrm{P}$ & 0.000 & 0.000 & 0.001 & 0.060 & 0.000 & 0.005 \\
\hline
\end{tabular}

1) No. of entries in each yield level: $\sim 100$ to 150 .

2) Student-Newman-Keuls procedure or multiple range test was used to compare different means. Means with different letters within columns differ significantly.

3) Yield increase achieved by fungicide treatment just before/during heading. 
Table 4. Actual yield increases $\left(\mathrm{kg} \mathrm{ha}^{-1}\right)$ obtained from a fungicide treatment at GS 45-61 at five disjunctive LBDs disease severities including Septoria tritici blotch, Stagonospora nodorum blotch and tan spot on leaf 2 at GS 75 during 1983-2005 in southern Sweden at two different yield levels based on the yield in fungicide treated plots. $\mathrm{N}=$ no. of entries

\begin{tabular}{|c|c|c|c|c|c|}
\hline $\begin{array}{c}\text { Severity of } \\
\text { LBDs on leaf } \\
2 \text { at GS } 75\end{array}$ & $\begin{array}{l}\text { Yield increase }\left(\mathrm{kg} \mathrm{ha}^{-1}\right) \text { in } \\
\text { fungicide-treated field } \\
\text { plots with yield levels } \\
\text { less than } 9250 \mathrm{~kg} \mathrm{ha}^{-1}\end{array}$ & $\begin{array}{l}\text { Yield increase }(\%) \text { in } \\
\text { fungicide-treated field } \\
\text { plots with yield levels } \\
\text { less than } 9250 \mathrm{~kg} \mathrm{ha}^{-1}\end{array}$ & $\begin{array}{l}\text { Yield increase }\left(\mathrm{kg} \mathrm{ha}^{-1}\right) \text { in } \\
\text { fungicide-treated field } \\
\text { plots with yield levels } \\
\text { more than } 9250 \mathrm{~kg} \mathrm{ha}^{-1}\end{array}$ & $\begin{array}{l}\text { Yield increase }(\%) \text { in } \\
\text { fungicide-treated field } \\
\text { plots with yield levels } \\
\text { more than } 9250 \mathrm{~kg} \mathrm{ha}^{-1}\end{array}$ & $\begin{array}{c}\text { P-value for } \\
\text { differences } \\
\text { between yield } \\
\text { levels } \\
\end{array}$ \\
\hline$>0 \%$ & $860(\mathrm{~N}=286)$ & 10.9 & $1130(\mathrm{~N}=312)$ & 10.6 & 0.0001 \\
\hline$>5 \%$ & $970(\mathrm{~N}=192)$ & 12.3 & $1230(\mathrm{~N}=225)$ & 11.4 & 0.0001 \\
\hline$>10 \%$ & $1050(\mathrm{~N}=141)$ & 13.5 & $1340(\mathrm{~N}=159)$ & 12.6 & 0.0001 \\
\hline$>15 \%$ & $1130(\mathrm{~N}=110)$ & 14.5 & $1430(\mathrm{~N}=106)$ & 13.5 & 0.0030 \\
\hline$>20 \%$ & $1210(\mathrm{~N}=87)$ & 15.5 & $1480(\mathrm{~N}=79)$ & 14.1 & 0.0210 \\
\hline
\end{tabular}


Table 5. Actual yield increases $\left(\mathrm{kg} \mathrm{ha}^{-1}\right)$ obtained from a fungicide treatment at GS 45-61 at five disjunctive LBDs disease severities including Septoria tritici blotch, Stagonospora nodorum blotch and tan spot on leaf 2 at GS 75 during 1983-2005 in southern Sweden at two different yield levels based on the yield in untreated plots. $\mathrm{N}=$ no. of entries

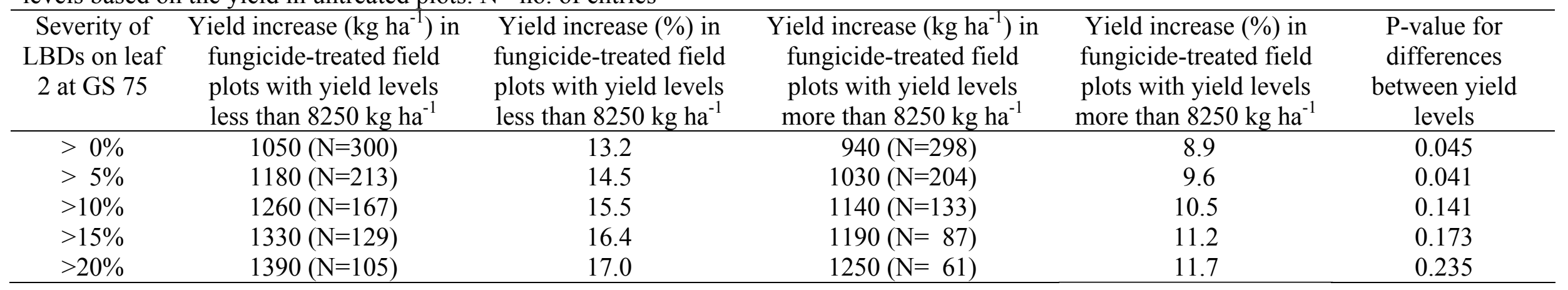


Table 6. Variance component analyses for nine variables, including LBDs (including S. tritici, S. nodorum, D. tritici-repentis), with year as random factor ${ }^{1)}$

\begin{tabular}{lccc}
\hline Dependent variables & No. of entries & Var(Year $^{2)}$ & ${\text { Var(Error })^{3)}}^{3}$ \\
\hline Yield & 764 & 57 & 43 \\
Yield increase & 764 & 40 & 60 \\
1000 grain weight (TGW) & 700 & 56 & 44 \\
Lodging & 711 & 18 & 82 \\
LBDs on leaf 3 at DC 55 & 593 & 28 & 73 \\
LBDs on leaf 2 at DC 75 & 598 & 43 & 57 \\
LBDs, maximal attack & 707 & 39 & 61 \\
Control of LBDs & 707 & 31 & 69 \\
Eyespot & 131 & 43 & 57 \\
Powdery mildew & 711 & 25 & 75 \\
Yellow rust & 514 & 26 & 74 \\
Brown rust & 563 & 48 & 52 \\
\hline
\end{tabular}

${ }^{1)}$ GLM, var(year) and var(error). Method: Restricted Maximum Likelihood Estimation (REML).

${ }^{2)}$ Estimates of the variance (\%) attributed to differences between years.

${ }^{3)}$ Estimates of the variance (\%) attributed to differences within years. 
Figure 1. Yield $\left(\mathrm{kg} \mathrm{ha}^{-1}\right)$ in Swedish winter wheat field trials carried out in southern Sweden during 1983-2005. Yield in untreated field plots marked $\Delta$ and yield in fungicide-treated (once GS 45-61) field plots marked $\boldsymbol{m}$. Lines show linear estimates of yield from untreated and treated field plots with equations and $\mathrm{R}^{2}$-values.

Figure 2. LBD (S. tritici, S. nodorum, D. tritici-repentis) severity (\%) on leaf 2 (flag leaf = leaf 1) at different growth stages (GS) in untreated plots during 1987, 2002, 1997, 2004, 1994 and 1992.

Figure 3. Yield increase $\left(\mathrm{kg} \mathrm{ha}^{-1}\right)$ due to a fungicide treatment at GS 45-61 and percentage attack of LBDs (S. tritici, S. nodorum, D. triticirepentis) on leaf 3 at GS $55(\Delta)$ and on leaf 2 at GS $75(\bullet)$ in southern Sweden, on average for each year 1983-2005. Bars showing standard deviation for yield increase. 


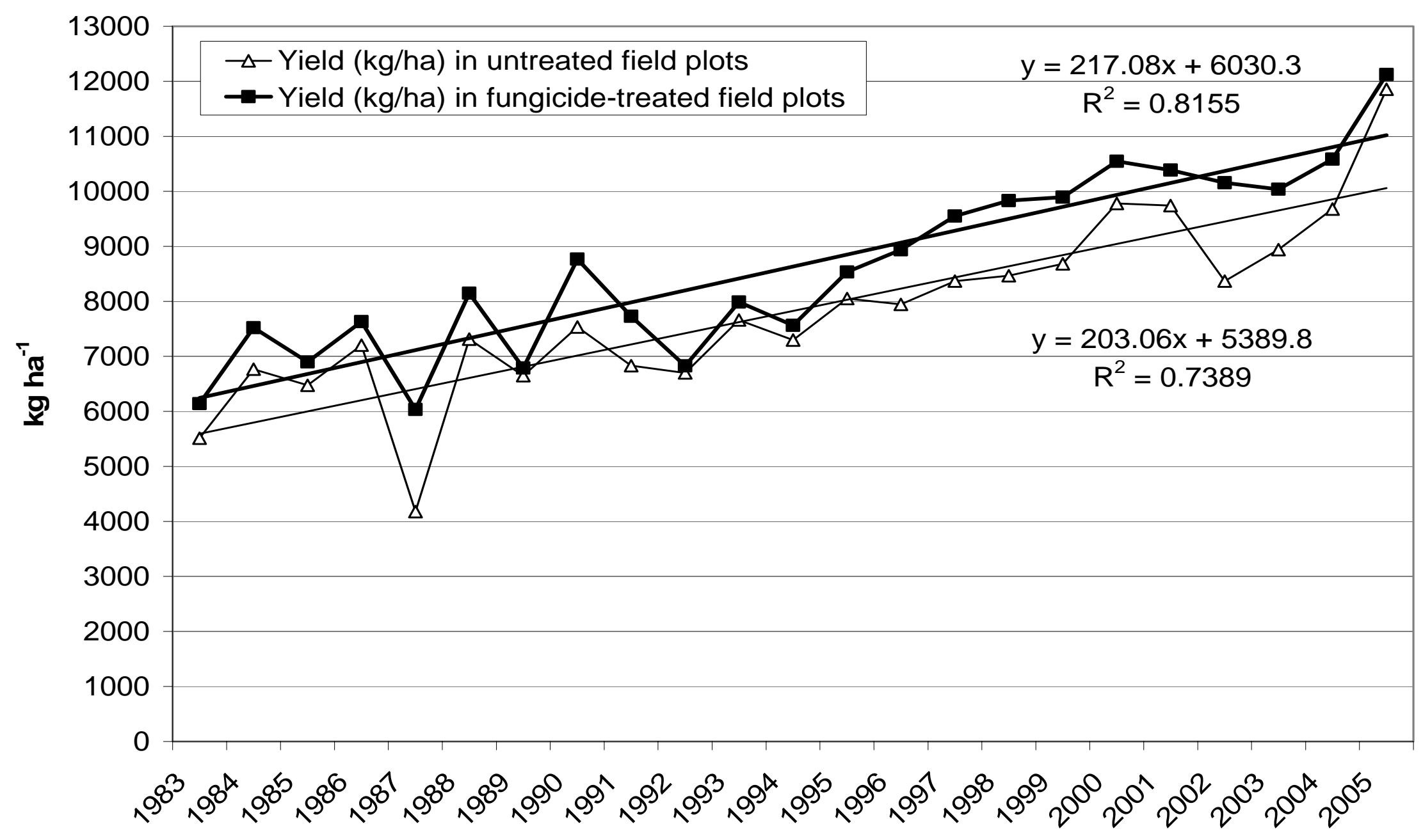

Figure 1. Yield $\left(\mathrm{kg} \mathrm{ha}^{-1}\right)$ in Swedish winter wheat field trials carried out in southern Sweden during 1983-2005. Yield in untreated field plots marked $\Delta$ and yield in fungicide-treated (once GS 45-61) field plots marked $\mathbf{m}$. Lines show linear estimates of yield from untreated and treated field plots with equations and $\mathrm{R}^{2}$-values. 


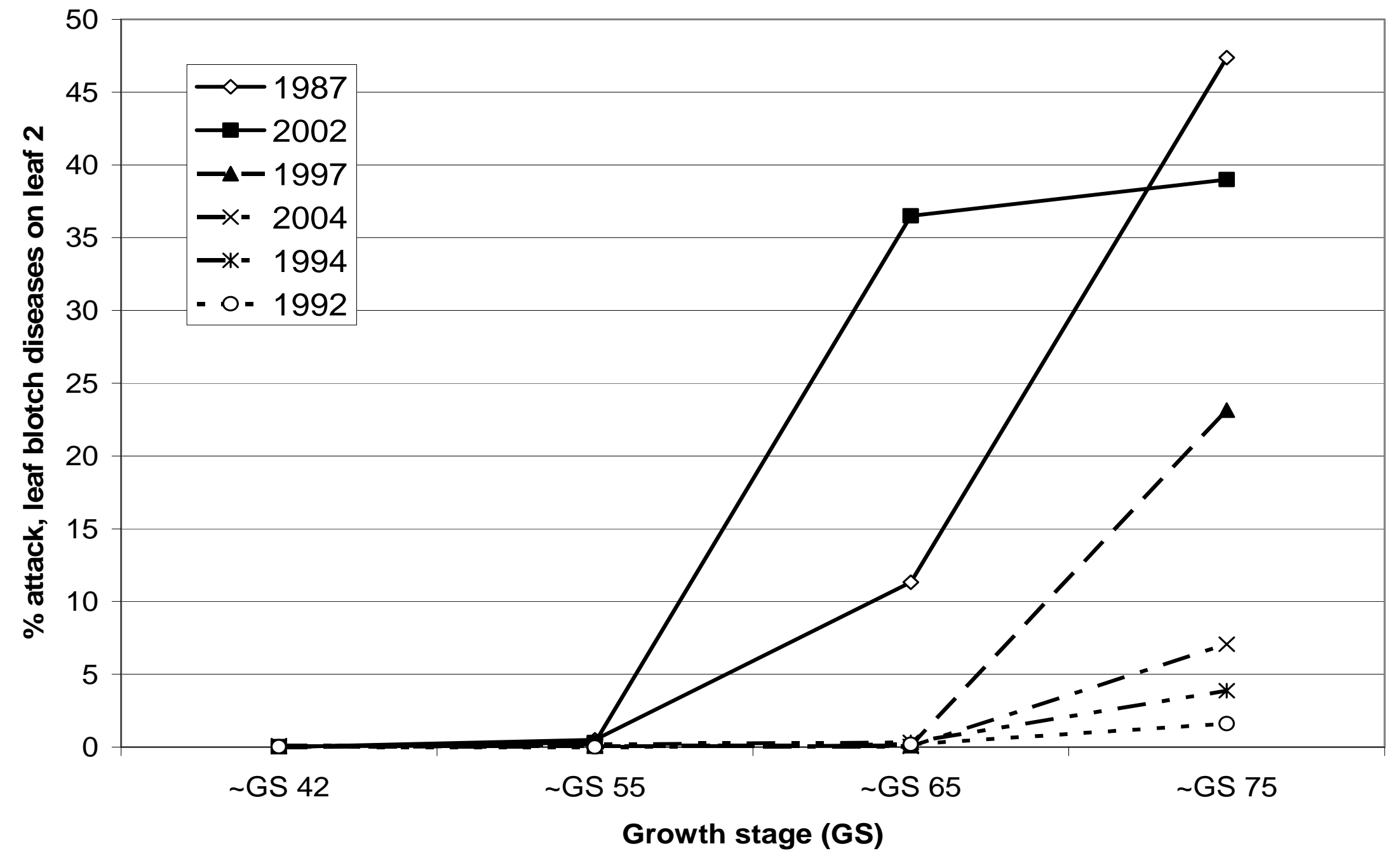

Figure 2. LBD (S. tritici, S. nodorum, D. tritici-repentis) severity (\%) on leaf 2 (flag leaf = leaf 1 ) at different growth stages (GS) in untreated plots during 1987, 2002, 1997, 2004, 1994 and 1992. 


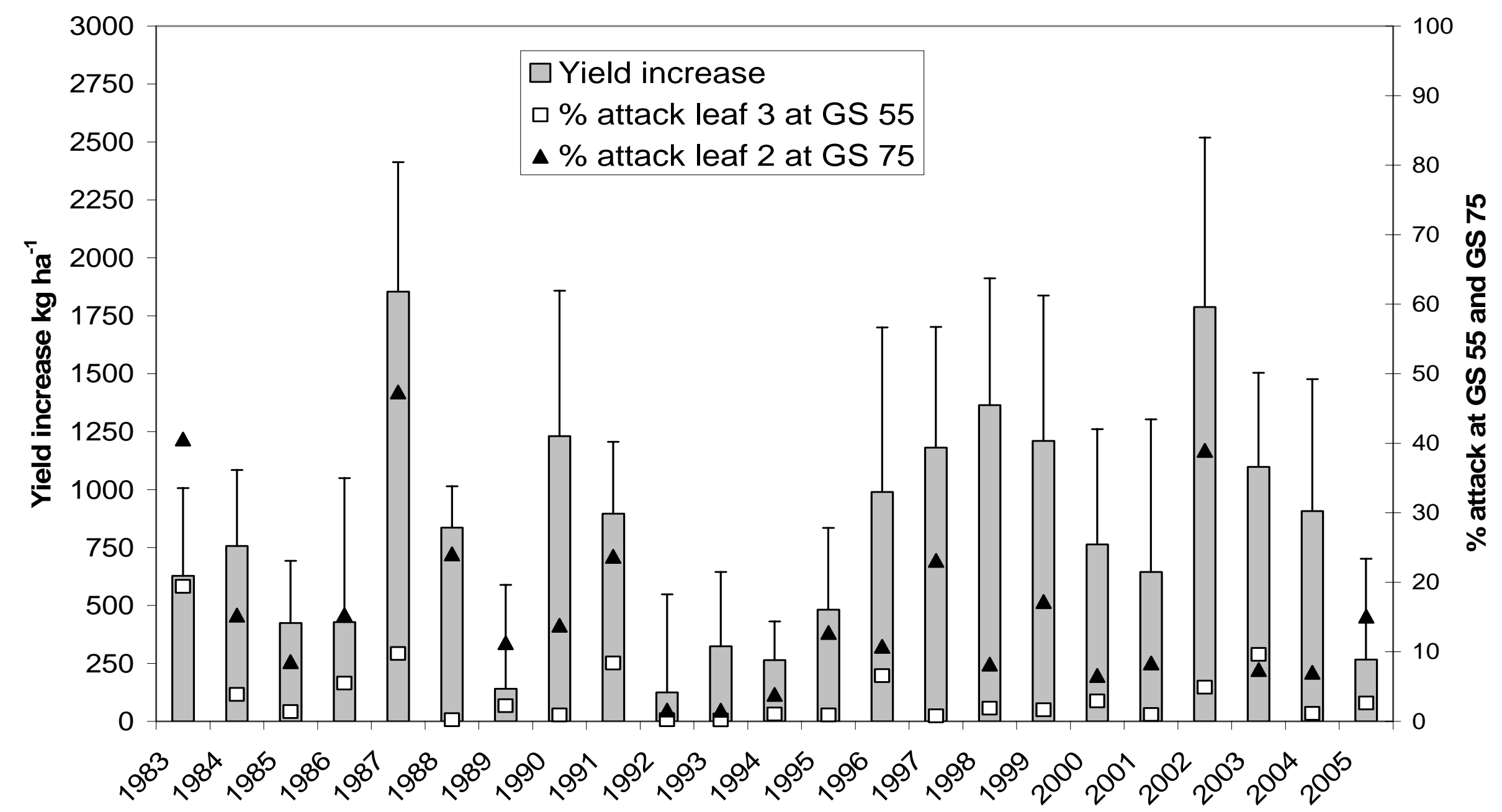

Figure 3. Yield increase $\left(\mathrm{kg} \mathrm{ha}^{-1}\right)$ due to a fungicide treatment at GS 45-61 and percentage attack of LBDs (S. tritici, S. nodorum, D. triticirepentis) on leaf 3 at GS $55(\Delta)$ and on leaf 2 at GS $75(\mathbf{\square})$ in southern Sweden, on average for each year 1983-2005. Bars showing standard deviation for yield increase. 